\title{
Vocational Trainings as a Tool for more Sustainable Employment in Republic of Kosovo: Gender Issues in Employment
}

\author{
Theranda Beqiri
}

PhD candidate

\author{
Doi:10.5901/ajis.2014.v3n2p359
}

\begin{abstract}
As Kosovo is moving to the market economy, the matching of its human capital should lead to the more skill-based labour participants when they enter the labour market, in order to match with the market needs. This paper aims to show the main factors of the labour market of Kosovo regarding gender, and the possibilities of improving the level of unemployment through vocational training. Republic of Kosovo has marked employment imbalance regarding gender, with the very low participation rates of women in the labour force, this was evident shown in the first years of transition Labour force participation and the level of employment has been low, and unemployment high. In 2002, labour force participation rate in Kosovo was $41.3 \%$, with male participation rate at $56 \%$ and women participation rate at only $27 \%$. From the data of the recent Labour Force Survey (2012) after ten years we find that the level of activity rate of women of working age is even lower, only one-in-five (17.8\% ) women of working age are active in the labour market. There are also large gender differences throughout the labour market. Among those in the labour force, unemployment is much higher for women than it is for men (40.0\% compared to $28.1 \%)$. Methodology used in this paper is based on the comparative analysis and interpretation of the available data from the Labour force Surveys conducted in Kosovo and also reports from World Bank and other governmental organizations (UNICEF, MLSW, ILO etc) during the last 10 years of transition. Women in Republic of Kosovo that are employed similarly to the ones in other transition countries are concentrated in education and caring activities. The disadvantages of the past and the persisting gender inequalities, call for policy implications of gender mainstreaming throughout the policy making and implementing of those policies that were adopted. A job creation policy targeting women may increase possibilities of the productive work and the possibility of creating jobs. It is also important to address not only gender inequalities in the labour market, but also related issues to education, with increasing level of unskilled jobseekers. Since this targeted group has the highest level of unemployment, vocational trainings in developing skills for employment in small and medium enterprises and family businesses are very important in new employment opportunities.
\end{abstract}

Keywords: Unemployment, Employment, Gender, Vocational Training.

\section{Introduction}

This paper aims to show the main factors of the labour market of Republic of Kosovo regarding gender, and the possibilities of improving the level of unemployment through vocational training. Republic of Kosovo has marked employment imbalance regarding gender, with the very low participation rates of women in the labour force, this was also the case in the first years of transition, labour force participation and the level of employment has been very low, and unemployment high. Skills development Women faces higher barriers than men in access to vocational education and training, especially in non-traditional occupations. Gender stereotypes dictating women's and men's skills and occupations tend to persist, causing occupational segregation in various Labour Markets (ILO 2012). Providing equal opportunities for women and men in access to relevant and quality education, vocational training, apprenticeships and workplace learning is key to overcome gender gaps in LM/employment (Strategy for Gender Mainstreaming in the Employment Sector 2010-15: aligned with ILO Action Plan for Gender Equality 2010-15: Phase II: Employment Sector. Geneva: ILO, 2012). Vocational education training is used as a wide concept, where in some countries is provided from the registered associations for Vocational education training, in some other countries is included in the curriculum of the upper secondary schools. Concept of Vocational Education Training might also be seen as on the job training and trainings that are done from the specific firms that are not registered in Kosovo from Ministry of Labour and Social Welfare. In Kosovo it is adapted the Law No. 02/L-42 Vocational Education and Training, and according to that law the "Vocational education and training" means education and training which aims to equip people of all ages with employable skills. The vocational education and training system is the complete system through which such education and training is provided; whereas "Vocational Education" is that part of vocational education and training that enables students, who 
have completed compulsory education, to achieve employable skills in a formal vocational education institutions; and "Vocational training" includes all activities which aim to provide practical knowledge, skills and attitudes for effective and efficient performance of activities within an occupation or group of occupations. According to Kosovo Education Strategic Plan (2011-2016) promoting high quality VET at secondary (and later higher non-tertiary) education in streams and profiles based on the needs of the labour market in Kosovo and abroad is a key goal, and especially the education of women and encouragement of women to study non-traditional subjects and enter VET classes, where for women who lack formal education they might receive some specific training depending of the needs of the enterprises and therefore it improve their economic status.

\section{Main Labour Market Indicators Regarding Gender in Republic of Kosovo}

From our assessment of the gender labour market in Kosovo and from the (LFS-Kosovo Agency for Statistics of 2012) it is noticed that there is a very low participation rate of females in active labour market participants (only $18.6 \%$ ), and together with a very low share of females in employment (only $10.3 \%$ ) and high with unemployment rate (44.4\%).

Fig.1. Unemployment by gender \%age

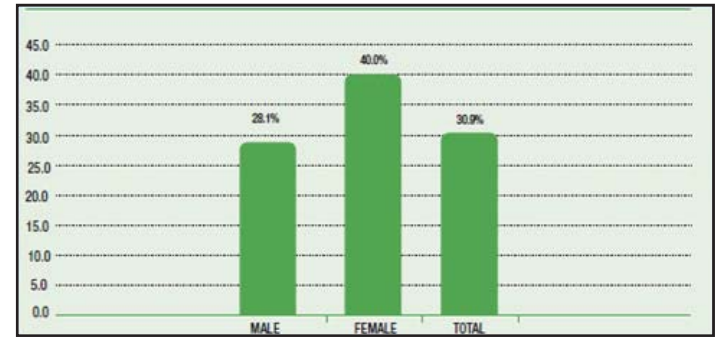

Source: Kosovo Labour Force Survey(LFS 2012)

Inequality by gender is significant in the labour market of Republic of Kosovo, unemployment rates for females are highest for those at the low educational qualifications and for unskilled, which is consistent with other transition countries. This might come from the low enrolment rate of females compared to males in the secondary education, which is shown in the table below the data from the LFS of 2009 on the level education in Kosovo we can see that the level of attainment of females drops significantly after $9^{\text {th }}$ grade

Table 1. Educational Attainment of Men and Women $2009, \%$ age 15 and older

\begin{tabular}{|l|c|c|c|}
\hline Education Level & Male & Female & Total \\
\hline No school & 1.4 & 4.9 & 3.2 \\
\hline Primary education (classes I-IV or I-V) & 4.3 & 11.1 & 7.7 \\
\hline 8/9-years school (classes V-VIII or V-IX) & 31.6 & 45.6 & 38.6 \\
\hline Upper secondary - vocational 2-3 years & 7.7 & 2.6 & 5.1 \\
\hline Upper secondary - vocational 4-5 years & 24.9 & 15.1 & 20.0 \\
\hline Upper Secondary - general (gymnasium) & 18.3 & 13.7 & 16.0 \\
\hline High-school* & 3.1 & 2.4 & 2.7 \\
\hline Tertiary / University & 7.8 & 4.3 & 6.1 \\
\hline Post university / Master & 0.8 & 0.2 & 0.5 \\
\hline Doctorate & 0.2 & 0.1 & 0.1 \\
\hline Total & $\mathbf{1 0 0}$ & $\mathbf{1 0 0}$ & $\mathbf{1 0 0}$ \\
\hline
\end{tabular}

Source: Kosovo Labour Force Survey (LFS 2009¹)

\footnotetext{
1 *In Kosovo, "High School" refers to the first two years of University Education, they existed until recent years, until the education
} system approved Bologna Process. 


\section{Employment, Job Creation and Vocational Training}

The main employer in Kosovo is the Public Sector, Government and State Owned Enterprises , and as such the biggest shares of women that are employed are in these sectors around $67 \%$ of the total share of employment. There is also a significant share of $23 \%$ in Private sector and around $10 \%$ in other international organizations and NGO's and private individuals (LFS 2009). This can also refer to the findings of Pastor As the economic development is still on its first steps, the need to be focused more on the investments in private sectors and incentivizing small enterprises is very important, since they seem to be one of the key sectors that can generate jobs creation and reduce the level of unemployment and gender imbalance in employment.

Table 2. Cumulative job seekers during the years

\begin{tabular}{|c|c|c|c|c|c|c|c|c|}
\hline \multirow{2}{*}{ Year } & \multicolumn{7}{|c|}{ Cumulative registered } \\
\cline { 2 - 9 } & TOTAL & Female & Unskilled & Semi-skilled & Skilled & Secondary school & High school & University \\
\hline 2003 & 282,305 & 128,238 & 164,535 & 13,321 & 26,406 & 73,194 & 2,357 & 2,492 \\
\hline 2004 & 301,314 & 138,116 & 177,943 & 12,948 & 27,557 & 78,286 & 2,316 & 2,264 \\
\hline 2005 & 319,721 & 147,927 & 189,776 & 13,236 & 28,764 & 83,215 & 2,375 & 2,373 \\
\hline 2006 & 326,026 & 152,198 & 193,894 & 13,655 & 29,283 & 84,291 & 2,302 & 2,601 \\
\hline 2007 & 334,595 & 156,679 & 199,648 & 14,009 & 29,767 & 86,309 & 2,211 & 2,651 \\
\hline 2008 & 335,942 & 158,120 & 200,969 & 13,695 & 29,025 & 87,087 & 2,213 & 2,953 \\
\hline 2009 & 338,895 & 161,131 & 203,764 & 13,355 & 28,849 & 87,681 & 2,184 & 3,062 \\
\hline 2010 & 335,260 & 160,856 & 200,709 & 12,594 & 28,353 & 87,874 & 2,155 & 3,575 \\
\hline 2011 & 325,261 & 157,922 & 195,394 & 11,831 & 27,214 & 84,597 & 2,002 & 4,223 \\
\hline 2012 & 259,338 & 119,374 & 148,749 & 8,884 & 22,393 & 72,616 & 1,646 & 5,050 \\
\hline
\end{tabular}

Source: Ministry of Labour and Social Welfare (MLSW)

As we can see from the table above the issues of long term unemployment is also a problem faced by females and males, and the highest levels of jobseekers during the 10 year period is of those of unskilled and those with only secondary school, therefore more vocational trainings for these target groups should be main priority of the vocational education centers which are within the MLSW with the different vocational trainings for those unskilled to match with the employment market demand and with the needs of private sector. According to Vocational Training Strategy (2012-2014) developed from the MLSW, they have identified the principles that are needed for VT to anticipate changes as :

- VT to become attractive and useful for individuals and society

- VT to become understandable for users - jobseekers, businesses, local communities, individuals and others

- VT to be accountable to society

- VT to be effective and efficient and to guarantee quality within the Kosovo training system

- VT to become more inclusive

They have marked that users of training services are only $2-5 \%$ of all registered jobseekers, therefore the information's on VT provided should be more available to jobseekers, and especially to females and minorities meaning more inclusive as emphasized in the VT strategy. Also the diversity of the trainings provided should go along with the different sectors that are in the process of investments from the private investors and government in order to be able to match the skills that are needed for the labour market demand. When it comes to jobseekers in Kosovo, and those that are employed, Men and women use slightly different search methods to find jobs. According to (Pastore et al 2013) young men and women, the vast majority of young people (53.5\%) rely on their network of family and friends. Direct contacts with prospective employers (19.8\%) and answering advertisements (15.0\%) are the second largest methods of job search. This is a sign of the lack of (public) intermediaries in the labour market able to bring vacancy news to unemployed young people. Men tend to use more frequently than women their network of friends and relatives. Similarly, they also tend to find a job through direct contacts with employers. Women found their job more frequently through advertisements and via information gathered at educational institution (Pastore, Francesco, Sarosh Sattar, and Erwin R. Tiongson (201 Discussion Paper No. 7461 June 2013 "Gender Differences in Earnings and Labour Supply in Early Career: Evidence from Kosovo's School-to-Work Transition Survey).

When it comes to vocational trainings they are mainly provided from the Vocational Centers until now there are 8 training centers in the main cities of Republic of Kosovo, as mentioned before they are under the MLSW and their main 
tasks are to identify training needs amongst unemployed people. In order to be eligible for the training programs offered by these centers, people should firstly be registered as unemployed at the Employment Offices. Although they offering free of charge vocational training courses in 28 occupational profiles We can see the low level of attendance during the years considering the level of unemployment and people that are searching for jobs.

Fig 2. Participation in vocational trainings in 12 months

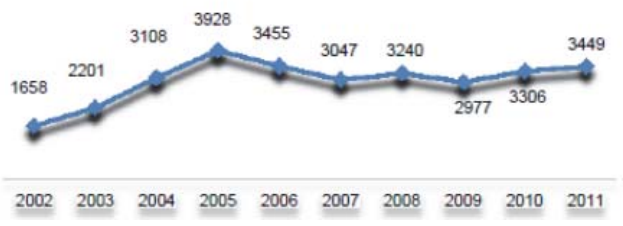

Source: Ministry of Labour and Social Welfare (MLSW)

There has been some minor improvements in providing vocational training to females and their activation rate(AR) shown in the table below according to the reports provided from the VT centers, but those are very minor to have an impact in increasing employment and the needs that are in the labour market of Kosovo .

Table 2. Vocational training by gender

\begin{tabular}{|l|c|c|c|c|c|c|c|}
\hline Trainings & $\begin{array}{c}\text { cumulated } \\
12-\text { Months }\end{array}$ & $\begin{array}{c}\text { Increase } \\
\text { to } 2010\end{array}$ & $\begin{array}{c}\text { Prop } \\
\text { Entries }\end{array}$ & $\begin{array}{c}\text { AR } \\
2010\end{array}$ & $\begin{array}{c}\text { GR } \\
2010\end{array}$ & $\begin{array}{c}\text { AR } \\
2011\end{array}$ & $\begin{array}{c}\text { GR } \\
2011\end{array}$ \\
\hline Female & 1602 & $6.02 \%$ & $46 \%$ & $0.94 \%$ & $77 \%$ & $0.99 \%$ & $81 \%$ \\
\hline Male & 1847 & $2.90 \%$ & $54 \%$ & $1.02 \%$ & $79 \%$ & $1.07 \%$ & $79 \%$ \\
\hline All & 3449 & $4.33 \%$ & $100 \%$ & $0.98 \%$ & $78 \%$ & $1.03 \%$ & $80 \%$ \\
\hline Unskilled Fem. & 299 & $9.12 \%$ & $33 \%$ & $0.24 \%$ & $66 \%$ & $0.26 \%$ & $71 \%$ \\
\hline Unskilled Male & 599 & $3.45 \%$ & $67 \%$ & $0.67 \%$ & $75 \%$ & $0.71 \%$ & $78 \%$ \\
\hline
\end{tabular}

Source: Ministry of Labour and Social Welfare (MLSW)

\section{Conclusions and Recommendations}

From our review of the data and the information above we can still conclude that the level of unemployment is very high in Republic of Kosovo. If we consider the level of activity rates of females from LFS 2002 they were $27 \%$ which is very low, and that level has decreased further to $17.8 \%$ in 2012 LFS. Maybe there are different samples and the data and the questionnaires are improved, and have higher quality informations based on the ILO standards in the 2012 survey, but that still gives a very high level of unemployment of $40 \%$ among females. The number of job seekers is very high, and from those the highest are among unskilled and the ones with the secondary education. The vocational training centers are trying to develop trainings but still the level of participants and especially female participants is very low. There is also a Law on vocational training and the Strategy in vocational training but the implementation of it, is in a very early stages considering the needs that are in the labour Market of Republic of Kosovo.

Recommendations for future actions;

- There is a need for public awareness that Vocational Trainings Centers are offering trainings free of charge, since it is emphasized that users of training services are only $2-5 \%$ of all registered jobseekers, therefore the information's on VT provided should be more available to jobseekers, and especially to females and minorities.

- A job creation policy targeting women may increase possibilities of the productive work and the possibility of creating jobs. It is also important to address not only gender inequalities in the labour market, but also related issues to education, with increasing level of unskilled jobseekers. Since this targeted group has the highest level of unemployment, vocational trainings in developing skills for employment in small and medium enterprises and family businesses are very important in new employment opportunities and job creations.

- Government, NGO's and the network of Vocational Training Centers should also focus on market needs and should register more centers or incentivize and expand also to private VTC centers in order to be able to reach 
more trainees considering the high level of jobseekers.

- In all VTCs, there is a course on Self-employment, which can be attended by all jobseekers who have a business idea, but the highest number of unemployed is unskilled, therefore for these courses should be offered some preparation training for the less educated.

- Secondary vocational schools should coordinate more with future employees, in order to develop a curricula according to the market needs

- More Nontraditional courses for females should be developed from Vocational Training Centers, as: Information technology, foreign languages, accountancy etc.

\section{References}

Pastore, Francesco, Sarosh Sattar, and Erwin R. Tiongson (201 Discussion Paper No. 7461 June 2013 "Gender Differences in Earnings and Labour Supply in Early Career: Evidence from Kosovo's School-to-Work Transition Survey."

Morley(2010). Morley, J. (2010), 'Fourth European Working Conditions Survey: Contribution to policy Development",Eurofound, available http://www.eurofound.europa.eu/pubdocs/2010/04/en/1/EF1004EN.pdf.

West, J. (2013) Vocational Education and Training in Eastern Europe: Transition and Influence, published by the Centre for Learning and Life Chances in Knowledge Economies and Societies at: http://www.llakes.org.

ILO (2012) Strategy for Gender Mainstreaming in the Employment Sector 2010-15: aligned with ILO Action Plan for Gender Equality 2010-15: Phase II: Programme and Budget 2012-13 / International Labour Office, Employment Sector. -Geneva: ILO, 2012 . ISBN: 978-92-2-125991-6 (print); 978-92-2-125992-3 (web pdf)

Kosovo Agency of Statistics "Results of the Labour Force Survey 2009", Social Statistics Department Labour Market Sector.

Kosovo Agency of Statistics "Results of the Labour Force Survey 2012", Social Statistics Department Labour Market Sector www.esk.rks-gov.ne

Ministry of Education Science and Technology "Kosovo Education Strategic Plan (2011-2016)" http://www.mashtgov.net/advCms/documents/KESP_2011 2016.pdf.

Ministry of Labour and Social (2012) " Labour and Employment" Annual Report 2011 , http://mpms.rks-gov.net/

Ministry of Labour and Social Welfare "Vocational Training Strategy 2012-2014" http://mpms.rks-gov.net/

Official Gazette Of The Republic Of Kosova / No. 7 / 26 March 2013, Pristina,LAW No. 04/L-138 "For Vocational Education and training"

Riinvest Institute (2003) ; Research Report 2003 "Labour Market and Unemployment in Kosova"

Statistical Office of Kosovo. 2010. "Education Statistics 2009-2010", Prishtina.

UNICEF (2008) GETTING TO LISBON: Assessing Vocational Training needs and Job Creation opportunities for Rural Woman Report Pristine

World Bank (2003) "Kosovo Labour Market Study: Policy Challenges of Formal and Informal

Employment," Report No. 25990. The World Bank, Washington.

World Bank (2010) "Kosovo: Unlocking Growth Potential: Strategies, Policies, Actions. A Country Economic Memorandum," Report No. 53185-XK. The World Bank, Washington

World Bank (2012) Kosovo: Gender Gaps in Education, Health and Economic Opportunities Poverty Reduction and Economic Management Unit Europe and Central Asia Region 
